\title{
Development of organizational and technological solutions for the implementation of projects of production programs of construction companies
}

\author{
Vitaliy Chulkov, Diana Zueva and Evgeniy Babushkin* \\ Moscow State University of Civil Engineering, Yaroslavskoe shosse, 26, Moscow, 129337, Russia
}

\begin{abstract}
The article describes the necessity of developing high-quality organizational and technological documentation (OTD). The purpose of the study is to identify finished in the regulatory regulation of the OTD and perfection of the qualimetric method of approach. Were considered organizational and technological solutions implemented in the programs of enterprises in order to regulate and optimize production. An analysis of the statistical study of completed capital construction projects and international experience became the basis for making proposals for changing the regulatory framework and additions to it.
\end{abstract}

\section{Introduction}

Organizational and technological documentation - a general definition of all documentation related to the management and organization of the construction process. The lack of mandatory requirements for its composition and availability adversely affects the quality of construction work. This article presents the results of research that confirm the need to build a new system of organizational and technological design.

\section{Materials and methods}

The statistical analysis of the completed capital construction objects served as a method of conducting the survey, depending on the availability or absence of organizational and technological documentation on the construction site. Also for comparison, the international practice in the field of organizational and technological design was studied.

\footnotetext{
Corresponding author: evgenii.babushkin@gmail.com
} 


\section{Literature Review}

The organizational and technological documentation (OTD) includes: the project of work production (PWP), the technological maps (TM), the technological regulations (TR), the labor process maps (LPM).

The project of the organization of construction (POC) is part of the project documentation and is being developed by the general design organization. It indicates the entire scope of work in consolidated points in accordance with the Decree of the Government of the Russian Federation of February 16, 2008 N87 "On the composition of sections of project documentation and requirements for their content." (PP RF N87) [1]. It contains technological solutions that are the basis for the development of a OTD.

While PWP - as part of the working documentation and developed by the general contractor or subcontractor. It carries in itself a more detailed development of the whole or part of the process. It is being developed in accordance with set of rules (SP) 48.13330.2011 "Organization of construction" [2].

Also, a general contractor or contractor organization develops: technological maps, technological regulations, maps of work processes.

The technological map - as part of the PPW for a separate process. It contains a sequence of actions and a description of the processes that the worker must perform. To date, there are no mandatory requirements for the development of technological maps in Russian legislation, there are only recommendations in the form of MDS 12-29-2006 "Methodological recommendations for the development and execution of a technological map" [3].

The technological regulation is a normative document similar to the TM, but is developed for internal use in the production of a particular product.

Map of labor processes - a document that reflects the rational organization of the workflow with the distribution of human and material resources.

Let's consider the scheme of interaction of participants by investment and construction activities that have developed to date (Figure 1). The first three links in this chain are: investor, developer and technical customer. These three agents can be represented by one person. Then, on a tender basis, the technical customer hires a research organization, a general contractor organization and a design organization. These three parties are required to have membership in a self-regulatory organization (SRO) to carry out their activities. Each of them can also hire subcontractors on the basis of the contract for subcontracting, for which the SRO will no longer be mandatory. The result of organizational and technological design of these organizations are all the above listed documents. 


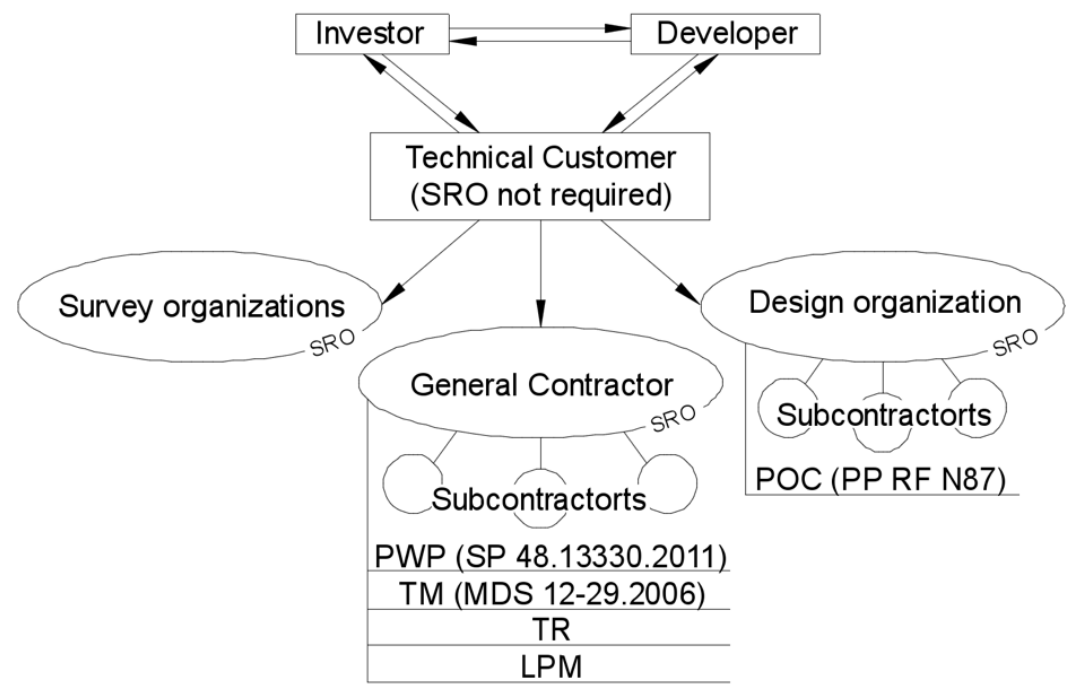

Fig 1. Participants in the construction and documentation developed by them

In accordance with the Urban Development Code of the Russian Federation [4], the signatories of the above-mentioned documents must be members of self-regulating organizations.

Self-regulating organization (SRO) is a non-profit organization that unites participants in the construction industry with the aim of regulating professional activities. Obtaining SRO in construction is necessary for the following organizations: survey, construction and design.

In the Urban Development Code of the Russian Federation [4] there is no requirement for membership in SRO for developers of organizational and technological documentation. There is a contradiction: the organization is competent for the development, but it is not competent to sign the organizational and technological documentation. To resolve this contradiction, only a change in regulatory regulation can occur.

Also worth noting the following. The last change in the Urban Development Code of the Russian Federation [4] in the field of OTD regulation was the mandatory membership of the specialist signing the sections of the project documentation in the National Register of Specialists. This means that only an engineer on the roster, as an expert with high professional qualifications, will have the right to sign the PWP. Accordingly, this will be the guarantor of the quality of the completed documentation. However, this problem remains solved not completely. The developers of other documents of organizational and technological design requirements are not presented.

Let's assume that all construction work can be divided into 3 categories (Table 1):

1) work of the first category - they include the main types of work with well-studied production technology (concreting, reinforcement, excavation, etc.). In this case, the impact of the absence of a OTD will be minimal: product quality and work safety will directly depend on the skills of workers

2) work of the second category - they can include work involving the use of new technologies, materials and equipment (jet-grouting, injection Hilti Rebar). The absence of a OTD will greatly affect the quality of products. This is due to the high complexity and responsibility of the work. This is due to the high complexity and responsibility of the work, the massive lack of work. 
3) the work of the third category is the work, the safety and quality of which is most dependent on the selected technology. These include work on the dismantling of loadbearing structures (disassembling). These works most strongly depend on OTD, since the technology of their production will depend on the integrity of all structures.

Table 1. Classification of general construction and special works.

\begin{tabular}{|l|l|l|l|}
\hline No. & $\begin{array}{l}\text { Category of } \\
\text { general } \\
\text { construction } \\
\text { and special } \\
\text { works }\end{array}$ & Category characteristic & $\begin{array}{l}\text { Examples of general construction } \\
\text { and special works }\end{array}$ \\
\hline 1. & I - th & $\begin{array}{l}\text { Minimum dependence of the } \\
\text { quality of the finished } \\
\text { construction products and the } \\
\text { availability of organizational } \\
\text { and technological } \\
\text { documentation }\end{array}$ & $\begin{array}{l}\text { Works, that the most tested and } \\
\text { often performed on most types of } \\
\text { objects - formwork, masonry, } \\
\text { reinforcement concrete, etc. } \\
\text { (without specific features of the } \\
\text { production and technology) }\end{array}$ \\
\hline 2. & $\begin{array}{l}\text { II - nd } \\
\text { category }\end{array}$ & $\begin{array}{l}\text { Thependence of the quality } \\
\text { products and the availability of } \\
\text { organizational and } \\
\text { technological documentation of } \\
\text { the 2nd kind }\end{array}$ & $\begin{array}{l}\text { Special types of work - welding, } \\
\text { injection, rebar technology, etc. } \\
\text { (Often - the works, produced by } \\
\text { specialized organizations) }\end{array}$ \\
\hline $\begin{array}{l}\text { The greatest dependence of the } \\
\text { quality of finished construction } \\
\text { products and the availability of } \\
\text { organizational and } \\
\text { technological documentation }\end{array}$ & $\begin{array}{l}\text { Dismantling works, provision of } \\
\text { counter-emergency measures, } \\
\text { demolition of buildings and } \\
\text { structures, hanging of structures } \\
\text { and other works of maximum } \\
\text { impact and the fastest possible } \\
\text { response to the safety and } \\
\text { reliability of structures and the } \\
\text { facility as a whole. }\end{array}$ \\
\hline
\end{tabular}

The results of gathering information on violations at 25 capital construction sites (monolithic reinforced concrete houses of 22-26 storeys in Moscow) are shown in Table 2.

Table 2. Dependence of the number of defects in finished construction products (by category) on the availability of this type of work with a set of organizational and technological documentation.

\begin{tabular}{|l|l|l|l|}
\hline \multirow{2}{*}{$\begin{array}{l}\text { The results of the } \\
\text { study, depending } \\
\text { on the security of } \\
\text { the workflow of } \\
\text { organizational } \\
\text { and technological } \\
\text { documentation }\end{array}$} & \begin{tabular}{l} 
Category of general construction and special works \\
\cline { 2 - 4 }
\end{tabular} & $\begin{array}{l}\text { II - nd } \\
\text { category }\end{array}$ & III categore of the volume of finished construction products with \\
\cline { 2 - 4 } $\begin{array}{l}\text { In the absence of } \\
\text { organizational } \\
\text { and technological } \\
\text { documentation }\end{array}$ & 0,25 & 0,5 & 0,5 \\
\hline
\end{tabular}




\begin{tabular}{|c|c|c|c|}
\hline $\begin{array}{l}\text { In the presence of } \\
\text { organizational } \\
\text { and technological } \\
\text { documentation }\end{array}$ & 0,25 & 0,3 & 0,3 \\
\hline $\begin{array}{l}\text { Conclusion based } \\
\text { on the results of a } \\
\text { statistical study }\end{array}$ & $\begin{array}{l}\text { The resulting defects are, } \\
\text { first of all, due to the } \\
\text { insufficient qualification } \\
\text { of the labor of the General } \\
\text { Contractor, errors of the } \\
\text { production managers, } \\
\text { discrepancies of the } \\
\text { Working documentation } \\
\text { (WD) and the quality of } \\
\text { the material used, etc. The } \\
\text { presence of organizational } \\
\text { and technological } \\
\text { documentation } \\
\text { neglectingly affects the } \\
\text { increase in the quality of } \\
\text { finished construction } \\
\text { products. }\end{array}$ & $\begin{array}{l}\text { The } \\
\text { availability of } \\
\text { correct and } \\
\text { complete } \\
\text { organizational } \\
\text { and } \\
\text { technological } \\
\text { documentation } \\
\text { allows } \\
\text { reducing the } \\
\text { number of } \\
\text { defects in } \\
\text { finished } \\
\text { construction } \\
\text { products by } \\
20 \% \text {. }\end{array}$ & $\begin{array}{l}\text { The situation with } \\
\text { the distribution of the } \\
\text { share of defective } \\
\text { products is actually } \\
\text { similar to the II- nd } \\
\text { category of work, but } \\
\text { the cost of the error } \\
\text { in this case is much } \\
\text { higher due to the } \\
\text { maximum effect and } \\
\text { the fastest response } \\
\text { of the defect to the } \\
\text { safety and reliability } \\
\text { of the structures and } \\
\text { the object as a whole }\end{array}$ \\
\hline
\end{tabular}

In special cases, the result of the absence of a OTD in the production of work may be an emergency or even the death of a worker. The first step in the investigation of this incident by state oversight bodies will be studied in detail by the OTD. If it is absent or incomplete, responsibility for the event will also be assigned to the head of work.

Also at these sites, the following study was carried out: the detection of violations at each stage of production of the main types of work, depending on the availability of PWP at the construction site (Table 3).

Table 3. Statistics of violations at capital construction sites

\begin{tabular}{|c|c|c|c|c|c|c|}
\hline & $\begin{array}{c}\text { PWP for the } \\
\text { preparatory } \\
\text { period }\end{array}$ & $\begin{array}{c}\text { PWP for } \\
\text { the zero } \\
\text { cycle of } \\
\text { work }\end{array}$ & $\begin{array}{c}\text { PWP for } \\
\text { the main } \\
\text { cycle of } \\
\text { work }\end{array}$ & $\begin{array}{c}\text { PWP for } \\
\text { finishing } \\
\text { work }\end{array}$ & $\begin{array}{c}\text { PWP for } \\
\text { internal } \\
\text { engineering } \\
\text { systems }\end{array}$ & $\begin{array}{c}\text { PWP } \\
\text { for the } \\
\text { device } \\
\text { roofing }\end{array}$ \\
\hline Developed & $99 \%$ & $62 \%$ & $98 \%$ & $48 \%$ & $\begin{array}{c}7 \% \text { (are developedat } \\
\text { the request of the } \\
\text { customer) }\end{array}$ \\
\hline $\begin{array}{c}\text { Infringements } \\
\text { on objects } \\
\text { without OTD }\end{array}$ & $8 \%$ & $15 \%$ & $32 \%$ & $23 \%$ & $41 \%$ & $39 \%$ \\
\hline $\begin{array}{c}\text { Infringements } \\
\text { on objects } \\
\text { with OTD }\end{array}$ & $3 \%$ & $7 \%$ & $19 \%$ & $18 \%$ & $26 \%$ & $21 \%$ \\
\hline
\end{tabular}

Statistics indicate that in the vast majority of cases the absence of PWP a negative impact on the quality of the work performed is negative. 
The qualitative development of PWP has a lot of advantages:

- safety and manufacturability of the construction industry;

- reduction of the construction time due to the reduction of the probability of production errors;

- improving the quality of construction supervision;

- for the Technical Customer - the guarantee of the required quality, estimate of estimated cost due to visibility of production processes;

- for the General Contractor - reliable and qualified personnel trained by a single organizational and technological documentation.

To study international experience, the situation with the availability of organizational and technological documentation in foreign countries was studied. The situation is such that in many countries there are no rules of regulation in the part of organization of construction production.

Table 4. Dependence of the number of violations on the complexity and responsibility of works.

\begin{tabular}{|c|c|c|c|}
\hline No. & Country & $\begin{array}{l}\text { Name of regulatory documents } \\
\text { in the field of construction }\end{array}$ & $\begin{array}{l}\text { The fact of the } \\
\text { existence of } \\
\text { regulations for the } \\
\text { organization of } \\
\text { construction }\end{array}$ \\
\hline 1. & Russian Federation & $\begin{array}{l}\text { Codes of Rules (SP), Building } \\
\text { Norms and Rules (SNiP) }\end{array}$ & + \\
\hline 2. & Belarus & $\begin{array}{l}\text { Technical normative legal acts } \\
\text { (TKP), Eurocode }\end{array}$ & + \\
\hline 3. & Poland & Eurocode & - \\
\hline 4. & Czech Republic & Eurocode & - \\
\hline 5. & Norway & Eurocode & - \\
\hline 6. & Finland & Eurocode & - \\
\hline 7. & France & Eurocode, AFNOR & + \\
\hline 8. & United Kingdom & Eurocode, BS & + \\
\hline 9. & Germany & Eurocode, DIN & + \\
\hline 10. & $\begin{array}{l}\text { United States of } \\
\text { America }\end{array}$ & ANSI, ASTM & + \\
\hline 11. & Japan & JIS & - \\
\hline 12. & China & GB & + \\
\hline
\end{tabular}

For example, in Belarus, documentation on the organization of construction includes a project of the organization of construction and a project for the production of work [5]. At the same time, without their approval, it is prohibited to carry out any construction and installation works, and any deviation from the decisions set forth in them is prohibited, without the consent of the organizations that have developed and approved them. Projects for the organization of construction are developed by general contracting construction and installation organizations. For certain types of work, projects for the production of work can be developed by organizations performing these works (subcontractors). During the construction of complex and experimental facilities, the projects for the production of works and technological maps in their composition should be developed by special design and technological organizations on the order of the customer. 
Table 5. Comparative analysis of the organization of building systems in different countries

\begin{tabular}{|c|c|c|c|}
\hline No. & $\begin{array}{l}\text { Comparison } \\
\text { criteria }\end{array}$ & Russion Federation & Belarus \\
\hline 1. & $\begin{array}{l}\text { Availability of } \\
\text { legal regulation } \\
\text { of OTD }\end{array}$ & SP 48.13300.2011 & TKP 45-1.03-161-2009 \\
\hline 2. & $\begin{array}{l}\text { Composition of } \\
\text { OTD }\end{array}$ & $\begin{array}{l}\text { the project of work production } \\
\text { (PWP), the technological maps } \\
\text { (TM), the technological } \\
\text { regulations (TR), the labor } \\
\text { process maps (LPM) }\end{array}$ & $\begin{array}{l}\text { project for the organization of } \\
\text { construction (POC), the } \\
\text { project of work production } \\
\text { (PWP), the technological maps } \\
(\mathrm{TM})\end{array}$ \\
\hline 3. & $\begin{array}{l}\text { Content of the } \\
\text { main OTD } \\
\text { document }\end{array}$ & $\begin{array}{l}\text { The project of work production } \\
\text { in full scope includes: } \\
\text { 1) the schedule of work on the } \\
\text { object; } \\
\text { 2) construction master plan; } \\
\text { 3) the schedule of receipt on the } \\
\text { object of building structures, } \\
\text { products, materials and } \\
\text { equipment; } \\
\text { 4) the schedule of movement of } \\
\text { workers on the object; } \\
\text { 5) the schedule of movement of } \\
\text { the main construction vehicles } \\
\text { on the object; } \\
\text { 6) flow charts to perform types } \\
\text { of work; } \\
\text { 7) layout of geodetic marks; } \\
\text { 8) explanatory note }\end{array}$ & $\begin{array}{l}\text { The structure of the project of } \\
\text { the organization of } \\
\text { construction includes: } \\
\text { 1) construction schedule; } \\
\text { 2) construction master plan; } \\
\text { 3) organizational and } \\
\text { technological schemes of } \\
\text { construction of the facility; } \\
\text { 4) statement of the need for } \\
\text { the main construction vehicles } \\
\text { and vehicles for construction } \\
\text { in general; } \\
\text { 5) calculation of the need for } \\
\text { personnel of builders by major } \\
\text { categories and periods of } \\
\text { construction } \\
\text { 6) explanatory note }\end{array}$ \\
\hline 4. & $\begin{array}{l}\text { Obligation to } \\
\text { use }\end{array}$ & $\begin{array}{l}\text { The project of work production } \\
\text { in full scope should be } \\
\text { necessarily developed: } \\
\text { 1) in any construction in the } \\
\text { urban area; } \\
\text { 2) at any construction on the } \\
\text { territory of the operating } \\
\text { enterprise; } \\
\text { 3) during construction in } \\
\text { difficult natural and geological } \\
\text { conditions, as well as } \\
\text { technically particularly complex } \\
\text { objects - at the request of the } \\
\text { authority issuing a building } \\
\text { permit or for performing } \\
\text { construction, installation and } \\
\text { special works }\end{array}$ & $\begin{array}{l}\text { The project of the organization } \\
\text { of construction is a mandatory } \\
\text { document for the customer, the } \\
\text { contracting construction } \\
\text { organizations, as well as } \\
\text { organizations providing } \\
\text { financing and material and } \\
\text { technical support for the } \\
\text { construction }\end{array}$ \\
\hline 5. & $\begin{array}{l}\text { Phases of an } \\
\text { investment and } \\
\text { construction } \\
\text { project with a }\end{array}$ & $\begin{array}{l}\text { OTD accompanies construction } \\
\text { phase }\end{array}$ & $\begin{array}{l}\text { OTD accompanies design and } \\
\text { construction phases }\end{array}$ \\
\hline
\end{tabular}




\begin{tabular}{|c|c|c|c|}
\hline No. & $\begin{array}{c}\text { Comparison } \\
\text { criteria }\end{array}$ & Russion Federation & Belarus \\
\hline & OTD & & \\
\hline 6. & $\begin{array}{l}\text { OTD } \\
\text { Developer }\end{array}$ & $\begin{array}{l}\text { PWP is developed by the } \\
\text { general project organization or } \\
\text { by its order another project } \\
\text { organization }\end{array}$ & $\begin{array}{l}\text { POC is developed by a general } \\
\text { project organization or by its } \\
\text { order another project } \\
\text { organization. }\end{array}$ \\
\hline 7. & $\begin{array}{l}\text { Reconciliation } \\
\text { of OTD }\end{array}$ & $\begin{array}{l}\text { PWP approved by the head of } \\
\text { the organization - the executor } \\
\text { of work }\end{array}$ & $\begin{array}{l}\text { POC approved by the head of } \\
\text { the organization - the executor } \\
\text { of work }\end{array}$ \\
\hline
\end{tabular}

\section{Results}

The following conclusions and suggestions can be considered the result of this study:

1. The need to improve the legislative framework

- the need to develop a new SP for construction control and quality assurance of construction products.

OTD in this case is the key to making technically correct decisions and choosing a more rational technology for the production of works

2. Improvement of the system of professional development of personnel by familiarization of the latter with organizational and technological documentation

- to develop the organization the standard of internal personnel policy, training new staff and re-qualifying the old

3. Support of organizational and technological potential in the part of tenders

-building of the tender bidding system in such a way that the priority would be given to contractors having an established base of organizational and technological documentation

4. Use of OTD as an additional tool of the customer's influence on the contractor -customer, having approved the OTD, may require the contractor organization to clearly fulfill its obligations.

\section{Conclusions}

The suggestions made in this article are aimed at improving the situation with organizational and technological design in general. These solutions are aimed at eliminating problems, which cause a lot of criticism on the quality of construction works, safety of labor, quality of construction control, and overall lagging behind the world standards of investment development.

\section{References}

1. Decree of the Government of the Russian Federation of February 16, 2008 N87 "On the composition of sections of project documentation and requirements for their content."

2. "SP 48.13330.2011. Set of rules. Organization of construction. Updated version SNiP 12-01-2004", section 7

3. "Guidelines for the development and execution of the technological map (MDS 1229.2006)", Central Research and Development and Experimental Institute for the Organization, Mechanization and Technical Assistance to Construction, Moscow, 2007

4. "Urban Development Code of the Russian Federation" from 29.12.2004 N 190-FZ (as amended on 03.08.2018) (with amendment and additional entry, effective from 01.09.2018) 
5. «TKP 45-1.03-161-2009. Technical code installed practices», Ministry of Architecture and Construction of the Republic of Belarus, Minsk, (2010)

6. Order of the Ministry of Regional Development of the Russian Federation of 30.12.2009 N 624 "On approval of the List of types of works on engineering surveys, preparation of project documentation, construction, reconstruction, overhaul of capital construction projects that affect the safety of capital construction projects"

7. Resolution of the Government of the Russian Federation of June 21, $2010 \mathrm{~N} 468$ "On the order of construction control in the implementation of construction, reconstruction and major repairs of capital construction."

8. Order of the State Construction Committee of the Russian Federation of 25.02.1999 N 39 "On improving the skills of specialists who exercise control over the quality of construction of facilities"

9. D. Topchiy, A. Shatrova, A. Yurgaytis, "Integrated construction supervision as a tool to reduce the developer's risks when implementing new and redevelopment projects", MATEC Web of Conferences 193 (2018)

10. D. Topchiy, E. Kochurina, "Environmental situation in construction, reconstruction and re-profiling of facilities in high-density urban development", MATEC Web of Conferences 193 (2018)

11. D. Topchiy, A. Tokarskiy, "Formation of the organizational-managerial model of renovation of urban territories", MATEC Web of Conferences 196 (2018)

12. D. Topchiy, A. Shatrova, "Formation of a basic management strategy for a construction organization in the implementation of projects of redevelopment of major urban areas", International Journal of Mechanical Engineering and Technology (2018)

13. D. Topchiy, A. Tokarskiy, "Designing of structural and functional organizational systems, formed during the re-profiling of industrial facilities", IOP Conference Series: Materials Science and Engineering (2018) 